\title{
PERSPECTIVES ON HIGHER EDUCATION
}





\section{PERSPECTIVES ON \\ HIGHER \\ EDUCATION}

\section{EIGHT DISCIPLINARY AND}

COMPARATIVE VIEWS

EDITED BY

BURTON R. CLARK

UNIVERSITY OF CALIFORNLA PRESS

Berkeley, Los Angeles, London 
L'niversity of California Press

Berkeley and Los Angeles, California

University of California Press, Ltd.

London, Fngland

Copyright (C) 1984 by The Regents of the University of California

Library of Congress Cataloging in Publication Data

Main entry under title:

Perspectives on higher education.

Papers presented at the 1982 summer seminar at the University of California, Los Angeles.

Includes index.

1. Education, Higher-History-Congresses. 2. Universities and colleges-Administration-Congresses. 3. Higher education and stateCongresses. 4. Fducational innovations-Congresses. 5. Social changeCongresses.

I. Clark, Burton R.

LA 174.P47 $1984 \quad 378 \quad 83-24342$

ISBN 0-520-05151-3

Printed in the United States of America

123456789 